\title{
Effects of pressure, shear, temperature, and their interactions on selected milk quality attributes
}

\author{
Jerish Joyner Janahar, ${ }^{1} \odot$ Alice Marciniak, ${ }^{1}$ V. M. Balasubramaniam, ${ }^{1,2 *}$ ๑) Rafael Jimenez-Flores, ${ }^{1}{ }^{\oplus}$ \\ and Edmund Ting ${ }^{3}$ \\ ${ }^{1}$ Department of Food Science and Technology, The Ohio State University, Columbus 43210 \\ ${ }^{2}$ Department of Food Agricultural and Biological Engineering, The Ohio State University, Columbus 43210 \\ ${ }^{3}$ Pressure BioSciences Inc., South Easton, MA 02375
}

\section{ABSTRACT}

The effects of pressure, temperature, shear, and their interactions on selected quality attributes and stability of milk during ultra-shear technology (UST) were investigated. The UST experiments include pressure (400 $\mathrm{MPa}$ ) treatment of the milk sample preconditioned at 2 different initial temperatures $\left(25^{\circ} \mathrm{C}\right.$ and $\left.15^{\circ} \mathrm{C}\right)$ and subsequently depressurizing it via a shear valve at 2 flow rates (low: 0.15-0.36 g/s; high: 1.11-1.22 g/s). Raw milk, high-pressure processed (HPP; $400 \mathrm{MPa}, \sim 40^{\circ} \mathrm{C}$ for 0 and $3 \mathrm{~min}$ ) and thermal treated $\left(72^{\circ} \mathrm{C}\right.$ for $\left.15 \mathrm{~s}\right)$ milk samples served as the controls. The effect of different process parameters on milk quality attributes were evaluated using particle size, zeta potential, viscosity, $\mathrm{pH}$, creaming, lipase activity, and protein profile. The HPP treatment did not cause apparent particle size reduction but increased the sample viscosity up to 3.08 $\mathrm{mPa} \cdot \mathrm{s}$ compared with $2.68 \mathrm{mPa} \cdot \mathrm{s}$ for raw milk. Moreover, it produced varied effects on creaming and lipase activity depending on hold time. Thermal treatment induced slight reduction in particle size and creaming as compared with raw milk. The UST treatment at $35^{\circ} \mathrm{C}$ reduced the effective diameter of sample particles from $3,511.76 \mathrm{~nm}$ (raw milk) to $291.45 \mathrm{~nm}$. This treatment also showed minimum relative lipase activity $(29.93 \%)$ and kept milk stable by preventing creaming. The differential effects of pressure, shear, temperature, and their interactions were evident, which would be useful information for equipment developers and food processors interested in developing improved food processes for dairy beverages.

Key words: milk, pressure, shear, temperature, quality

Received June 11, 2020.

Accepted October 9, 2020.

*Corresponding author: balasubramaniam.1@osu.edu

\section{INTRODUCTION}

In recent times there has been increasing demand for foods of fresh-like quality that retain nutrients with minimal or no addition of synthetic ingredients such as emulsifiers and preservatives. To satisfy such demand, the food industry adapted alternative food preservation methods such as high-pressure processing (HPP). Several pressure-pasteurized products are available in the market, including juices, meat, seafood, salads, and ready-to-eat meals. Commercial success of batch highpressure technologies for liquid foods led the industry to seek continuous methods of pressure treatment for various commodities (Martínez-Monteagudo et al., 2016).

Ultra-shear technology (UST), or high-pressure homogenization, is a continuous HPP technique that involves pressurization of liquid foods up to $400 \mathrm{MPa}$ and subsequent depressurization by passage through tiny clearance in a shear valve. When the milk sample exits the shear valve, due to significant pressure difference across the valve, the pressure energy is converted into kinetic energy. This kinetic energy is dissipated as heat energy to raise the temperature of the fluid and as heat loss to the surroundings (Martínez-Monteagudo et al., 2016). Remaining kinetic energy is spent on sample physical and structural modifications (mixing, emulsification, dispersion, particle size, enzyme, and microbial reduction) via intense mechanical forces, such as shear, turbulence, or cavitation. Thus, depending upon the product initial temperature and process pressure, UST treatment can result in pasteurization or commercial sterilization effects along with structural modification in the treated liquid.

Fluid milk has been a staple beverage of American life and has been well researched. According to USDA, around 1.72 million metric tons of packaged fluid milk products were shipped in North America by milk handlers in April 2017. Over the years, several studies reported the cumulative effect of ultra-shear treatment on milk quality attributes (Hayes and Kelly, 2003; Datta 
et al., 2005; Hayes et al., 2005; Diels and Michiels, 2006; Pereda et al., 2007). Ultra-shear technology is found to be effective in inactivating various microorganisms including bacterial spores, enzymes, and stabilizing emulsions such as milk and milk-based beverages (Thiebaud et al., 2003; Hayes et al., 2005; Diels and Michiels, 2006; Martínez-Monteagudo et al., 2017). The treatment is also reported to cause changes in the milk protein structure through partial disassociation and coagulation properties in milk (Sandra and Dalgleish, 2007; Zamora et al., 2007; Roach and Harte, 2008). Most of these studies were conducted at pressures below 350 MPa. Moreover, limited efforts were made to separate the contributions of individual process parameters (pressure, heat, and shear) and their interactions on product quality. Thus, the relative importance of different UST process parameters on quality attributes is not well understood. In addition, researchers often subject the fluid food samples to multiple pressure-shear intensity treatments (Diels and Michiels, 2006; Maresca et al., 2011; Ruiz-Espinosa et al., 2012). Although the use of multiple passes was intended to improve the effectiveness of the treatment (Tahiri et al., 2006; Maresca et al., 2011), this may not be practically useful for the industrial food-processing environment. The objective of this research is to evaluate the effects of pressure, shear, temperature, and their interactions during the UST process on selected quality attributes of milk.

\section{MATERIALS AND METHODS}

\section{Materials}

Raw Milk. Raw cow milk was obtained from The Ohio State University Dairy Farm, Columbus, and transported within 30 min to the OSU Emerging Food Process Technology pilot plant. Using Sprint rapid protein analyzer and SMART Trac II Moisture \& Fat Analyzer (CEM Corporation, Matthews, NC), raw milk characteristics were estimated $(3.28 \pm 0.04 \%$ protein, $4.15 \pm 0.08 \%$ fat, and $12.97 \pm 0.06 \%$ TS). Immediately upon arrival, the milk was stored refrigerated $\left(<5^{\circ} \mathrm{C}\right)$ for a maximum of $1 \mathrm{~d}$ before conducting experiments.

Ultra-Shear Technology Laboratory Tester. A custom fabricated benchtop UST laboratory tester (PBI, Easton, MA) capable of attaining $400 \mathrm{MPa}$ pressure was used in the present study (Figure 1). Equipment components include raw product reservoir, pressure generating system, pressure chamber, shear valve, cooling heat exchanger, and processed product reservoir. A $30-\mathrm{mL}$ dispensing syringe was used as the raw product reservoir.

The pressure generating system employed compressed air to move a small plunger to pressurize water (pressure-transmitting fluid). Subsequently, the fluid transmitted the pressure to the milk sample via freemoving piston (called an isolator). The pressurized fluid food is then depressurized via shear valve.

The shear valve consists of a spherical ceramic ball placed over a circular valve seat. The force of the ceramic ball on the valve seat can be adjusted using a micrometer to vary the gap for fluid passage. When the fluid pressure is sufficient to overcome the force provided by the micrometer against the ceramic ball, fluid passes through the gap between the ball and valve seat (Figure 2). The pressure and temperature at various locations were collected using a data acquisition system $(\mathrm{PBI})$.

\section{Methods}

UST Treatment. A temperature-preconditioned milk sample was fed into a UST unit, and samples were treated at a pressure of $400 \mathrm{MPa}$ and subsequently decompressed via shear valve. Based on preliminary studies, raw milk samples were preconditioned at initial temperatures of 15 and $25^{\circ} \mathrm{C}$ to achieve 35 and $65^{\circ} \mathrm{C}$ process temperature after treatment. A typical pressure process run consists of pressurization of fluid milk $(\sim 2.5$ to $3 \mathrm{~mL})$ followed by depressurization by passing through the shear valve. Based on preliminary experiments, it was ensured milk sample received certain target pressure and temperature before collection at the exit of the shear valve (see Pressure-Thermal History of UST-Treated Samples section below). The UST process runs were repeated (up to 10 times) to collect the desired sample volume $(\sim 30 \mathrm{~mL})$ for various quality analysis. It is to be noted that the product exiting shear valve was not recirculated or passed back into the equipment in the present study. The mass of samples collected during different process runs were recorded to calculate mass flow rate through the shear valve.

Thermal Effects During UST Treatment. The whey proteins in milk are sensitive to temperatures around $65^{\circ} \mathrm{C}$, with $\alpha$-lactalbumin, bovine serum albumin and immunoglobulin $\mathrm{G}$ having initial denaturation temperatures of 62,64 and $72^{\circ} \mathrm{C}$ respectively (Lee, 1992). On the other hand, at temperatures below $50^{\circ} \mathrm{C}$, the thermal effects on product quality and safety often can be assumed to be negligible (Khalil and Villota, 1988). Thus, UST experiments were carried out at $65^{\circ} \mathrm{C}$ and $35^{\circ} \mathrm{C}$ to evaluate pressure-thermal-shear effects and pressure-shear effects respectively (Figure 3).

To achieve $65^{\circ} \mathrm{C}$ process temperature in milk at the exit of shear valve, milk was equilibrated to $25 \pm 2^{\circ} \mathrm{C}$ for $30 \mathrm{~min}$ and pressurized up to $400 \mathrm{MPa}$ and sheared under 2 different flow rates; low $(0.36 \pm 0.11 \mathrm{~g} / \mathrm{s})$ and high $(1.11 \pm 0.12 \mathrm{~g} / \mathrm{s}) . A 35^{\circ} \mathrm{C}$ process temperature 




Figure 1. Schematic diagram of bench-scale ultra-shear technology laboratory tester.

was realized by controlling the initial milk temperature and wrapping the shear valve with a flexible cooling pad for removal of heat in the shear valve. Experiments involved equilibrating the milk at $15 \pm 2^{\circ} \mathrm{C}$ for $30 \mathrm{~min}$, pressurizing up to $400 \mathrm{MPa}$ and subsequently shearing under low $(0.15 \pm 0.01 \mathrm{~g} / \mathrm{s})$ and high $(1.22 \pm 0.20$ $\mathrm{g} / \mathrm{s})$ flow rates. It is worth noting that this research employed a constant pressure intensifier. The flow rate can be changed by changing the restriction in the valve.
This would not change the pressure drop. During the period of discharge, the flow is continuous.

Control Samples. The experiments also used 3 sets of control samples. First, the untreated raw milk served as a control. To investigate the pressure-only (400 $\mathrm{MPa}$ ) effects, tests were conducted using a batch HPP system. Thermal-only effects were investigated using a laboratory scale thermal pasteurizer. The equipment and experimental details are described below.


Figure 2. Schematic diagram of operation of shear valve in ultra-shear technology equipment. (a) When the ball valve is in closed position no liquid flow is allowed via the valve seat. (b) When the micrometer is rotated counter-clockwise, the valve pin moves up, gradually opens the ball valve, and allows liquid to exit through the open shear valve. 
Pressure Treatment. High-pressure treatment of milk samples was performed using batch HPP equipment (PT1 pressure kinetic testing unit, Avure Technologies, Kent, WA) by adapting the procedure previously published by our laboratory (Dhakal et al., 2016; Balasubramaniam et al., 2016). Briefly, milk $(\sim 2.5 \mathrm{~mL})$ pouches at an initial temperature of $25 \pm 2^{\circ} \mathrm{C}$ were pressurized up to $400 \mathrm{MPa}$ for 2 different (0 and $3 \mathrm{~min}$ ) pressure holding times. The process temperatures for 0 and $3 \mathrm{~min}$ were $40.66 \pm 0.82^{\circ} \mathrm{C}$ and $40.97 \pm 0.07^{\circ} \mathrm{C}$, respectively.

Thermal Treatment. Raw milk was thermally treated at a temperature of $72^{\circ} \mathrm{C}$ and held for $15 \mathrm{~s}$, followed by cooling to $5^{\circ} \mathrm{C}$ at a flow rate of $3 \mathrm{~L} / \mathrm{min}$, using MicroThermics UHT/HTST Lab-25HV (MicroThermics, Inc., Raleigh, NC) system. This process is analogous to the industrial HTST process, except that the homogenization operation was excluded.

Analysis of Quality Attributes. The quality attributes of UST-treated and various control samples were evaluated using particle size, zeta potential, viscosity, $\mathrm{pH}$, creaming, lipase activity, and protein profile analyses using SDS-PAGE.

Particle Size. The particle size of untreated and treated samples was analyzed by dynamic light scattering technique in a particle size analyzer (NanoBrook, ZetaPALS, Brookhaven, Holtsville, NY). Samples were diluted with ultra-pure water in the ratio of $1: 1,000$. Milk fat particle refractive index of $1.45-0.01 \mathrm{i}$ and dispersant refractive index of 1.33 were used (Matsumiya et al., 2017). Particle size was measured within $1 \mathrm{~h}$ after treatments.

Effective diameter $\left(D_{\text {eff }}\right)$ represents the average size of particles in the sample, which is the hydrodynamic diameter measured by intensity of the light scattered by each particle.

$$
\mathrm{D}_{\text {eff }}=\frac{\Sigma N d^{6}}{\Sigma N d^{5}}
$$

where $N$ is the number of particles and $d$ is the particle diameter.

The polydispersity index (PDI) is a measure of the nonuniformity in the particle size distribution. It is a dimensionless number ranging from 0 to 1.0, with values close to 0 indicating uniform and homogeneous distribution.

The mean diameter by volume $\left(\mathrm{D}_{4,3}\right)$ is the diameter of sphere of equivalent volume for measured particles.

$$
\mathrm{D}_{4,3}=\frac{\Sigma N d^{4}}{\Sigma N d^{3}}
$$



Figure 3. Flowchart summarizing process conditions in raw milk treatments and analysis. 
The mean diameter by surface $\left(\mathrm{D}_{3,2}\right)$ is the particle diameter with the same specific surface as that of the whole distribution.

$$
\mathrm{D}_{3,2}=\frac{\Sigma N d^{3}}{\Sigma N d^{2}}
$$

The particle size distribution of samples given as differential distribution versus mean diameter by volume was estimated using the BIC Particle Solutions software version 3.5 (Brookhaven Instruments, 2020).

Zeta Potential. Zeta potential measurements of all samples were performed using phase analysis light scattering technique in a zeta potential analyzer (NanoBrook, ZetaPALS, Brookhaven). Samples diluted with ultra-pure water in the ratio of 1:1,000 were used. The electrophoretic mobility of particles was measured using light scattering with a detection angle of $15^{\circ}$. Zeta potential was determined from mobility data using Smoluchowski model.

Viscosity. Viscosities of all samples were measured at $23 \pm 2^{\circ} \mathrm{C}$ using Brookfield viscometer (LV DV2T Extra, Brookfield Engineering Laboratories Inc., Middleboro, MA) with UL adapter. Approximately $16 \mathrm{~mL}$ of sample was placed in the sample cup, and the spindle was inserted. Viscosity was measured in $\mathrm{m} . \mathrm{Pa} \cdot \mathrm{s}$ at 60 rpm (shear rate of $73.38 \mathrm{~s}^{-1}$ ) for $180 \mathrm{~s}$.

$p \boldsymbol{H}$. The $\mathrm{pH}$ of all samples was measured at $23 \pm 2^{\circ} \mathrm{C}$ using a benchtop pH meter (Mettler Toledo, Columbus, $\mathrm{OH})$.

Creaming. To study creaming, the procedure described by Huppertz et al. (2003) was used with modification considering scale of operation. Ten milliliters of milk samples were placed in closed graduated tubes and stored undisturbed at refrigerated temperature $<5^{\circ} \mathrm{C}$. The volume of cream or fat portion rising to top of the tube was noted to the nearest $0.5 \mathrm{~mL}$ for $15 \mathrm{~d}$ and expressed as $\mathrm{mL}$ of cream $/ 10 \mathrm{~mL}$ of milk.

Lipase Activity. The lipase activity in the untreated, HPP-treated, and UST-treated milk samples were determined using the procedure reported by Humbert et al. (1997) with slight modification. Before analysis, an inhibiting mixture and substrate (Humbert et al., 1997) as well as clarifying reagent (Linden et al., 1991) were prepared. For analysis, sample and blank tubes were taken. In sample tubes, $0.5 \mathrm{~mL}$ of milk was taken, and $2 \mathrm{~mL}$ of $0.05 M$ Tris buffer with $\mathrm{pH} 7.6$ was added. Only the blank tube was added with $0.4 \mathrm{~mL}$ of inhibiting mixture. Both tubes were kept at $37^{\circ} \mathrm{C}$ for $15 \mathrm{~min}$ for incubation. The substrate was then added to both tubes, shaken, and kept at $37^{\circ} \mathrm{C}$ for $10 \mathrm{~min}$ for incubation. Then $0.4 \mathrm{~mL}$ of inhibiting mixture was mixed with sample tubes only. At last, $2 \mathrm{~mL}$ of clarifying reagent was mixed in all tubes and kept at $37^{\circ} \mathrm{C}$ for 3 to $5 \mathrm{~min}$. The clarified mixtures were taken in cuvette within 15 min to be read with Fisherbrand accuSkan GO UV/ Vis Spectrophotometer (Thermo Fisher Scientific, Waltham, MA) absorbance at $420 \mathrm{~nm}$. A standard curve developed using 0 to $40 \mu \mathrm{mol}$ per assay was used to convert the absorbance values to $\mu$ mol $p$-nitrophenol and calculate the relative lipase activity (\%).

Sodium Dodecyl Sulfate Polyacrylamide Gel Electrophoresis. The SDS-PAGE of raw milk in comparison to HPP- and UST-treated samples was carried out using mini precast gels (4-20\% stain-free protein gels, 10 wells) as described by Takagi et al. (2007) with reagents sourced from Bio-Rad Laboratories (Hercules, CA), based on the method described by Marciniak et al. (2018) with slight modification. Twenty microliters of each sample (diluted in PBS buffer) were added to $20 \mu \mathrm{L}$ of native sample buffer (contains $62.5 \mathrm{~m} M$ Tris-HCl, pH 6.8, $40 \%$ glycerol, $0.01 \%$ bromophenol blue). Twenty microliters of this solution was loaded into an individual well. The running buffer was $10 \times$ Tris/glycine/SDS buffer. The standards used were SDS-PAGE MW standard-broad range (Bio-Rad Laboratories). Electrophoresis was carried out at $15 \mathrm{~mA} /$ gel in the mini-protean tetra vertical electrophoresis cell until the tracking dye reached the bottom of the gel. The gel images were then acquired by ChemiDoc Imaging System (Bio-Rad Laboratories) for further analysis.

Protein Aggregation in UST-Treated Samples. To determine the amount of protein denatured or aggregated in the samples treated with UST at different temperatures, a procedure described by Pizzano et al. (2012) was used with slight modification. A 5-mL aliquot of UST-treated milk sample was taken, and the $\mathrm{pH}$ of each sample was adjusted to 4.6 by adding 1 $\mathrm{N} \mathrm{HCl}$ under $\mathrm{pH}$ meter. The aliquot was then centrifuged at $4,000 \mathrm{rpm}(3,739 \times \mathrm{g})$ at $25^{\circ} \mathrm{C}$ for $15 \mathrm{~min}$ in a Sorvall Legend XFR Centrifuge (Thermo Fisher Scientific). The fat portion, if separated on top, was removed manually. The protein content in supernatant was determined in duplicate using Sprint rapid protein analyzer (CEM Corporation).

Statistical Analysis. Statistical significance of the data was analyzed using ANOVA using IBM SPSS Statistics 20 (IBM Corporation, Armonk, NY) statistical analysis package. All process runs and instrumental analyses were done at least in triplicate unless mentioned otherwise. The data were expressed as mean \pm SD. Tukey's honest significance difference test was used for comparisons between means. The level of significance was determined at $P \leq 0.05$. 


\section{RESULTS AND DISCUSSION}

\section{Pressure-Thermal History of UST-Treated Samples}

During UST treatment, the fluid milk preconditioned at certain initial temperature is pressurized up to 400 $\mathrm{MPa}$ in the pressure chamber and passed on to the shear valve. In pressure chamber, the product temperature transiently increased $\left(\sim 3^{\circ} \mathrm{C} / 100 \mathrm{MPa}\right)$ due to adiabatic heating (Rasanayagam et al., 2003). In addition, the temperature of the fluid increases almost instantaneously as it passes through the shear valve $\left(\sim 20^{\circ} \mathrm{C} / 100 \mathrm{MPa}\right.$; Martínez-Monteagudo et al., 2017). This temperature rise during pressure discharge in shear valve is a pure thermodynamic effect that takes place as a result of conversion of potential pressure energy to kinetic energy and subsequently to thermal energy. In theory, the temperature rise in the fluid during discharge is dependent only on the work done (pdV) on the fluid (Martínez-Monteagudo et al., 2016). However, in practical conditions, the temperature rise can vary depending on other factors such as shear valve geometry and flow rate, due to the varying heat loss. For example, when a small volume of fluid is passed at a low flow rate through shear valve with higher mass and longer fluid path, most of the heat generated by shear would be lost to the surrounding environment (e.g., valve body, tubing) resulting in lesser temperature of fluid at shear valve exit, relative to theoretical maximum. On the other hand, in high rate flow condition, the fluid would have lesser ability to lose heat and thus exit at a relatively higher temperature. Therefore, it is essential to understand the pressure-thermal history of the fluid product during UST processing. The pressure-thermal histories of milk samples exiting shear valve at various flow rates during UST treatment are shown in Figures 4 and 5.

\section{Pressure-Thermal History of $65^{\circ} \mathrm{C}$ UST-Treated Samples}

At the beginning of UST experiments at $65^{\circ} \mathrm{C}$ (Figures $4 \mathrm{a}$ and $4 \mathrm{~b}$ ), it can be observed that temperature fell short of target process temperature during the first 2 process runs. The heat energy generated during these process runs were primarily used in warming up the shear valve, which was maintained at ambient temperature. During the third process run, target process tem-

(a)



(b)



Figure 4. Pressure-temperature history during $65^{\circ} \mathrm{C}$ ultra-shear technology treatment for 10 process runs at (a) low flow rate and (b) high flow rate. 


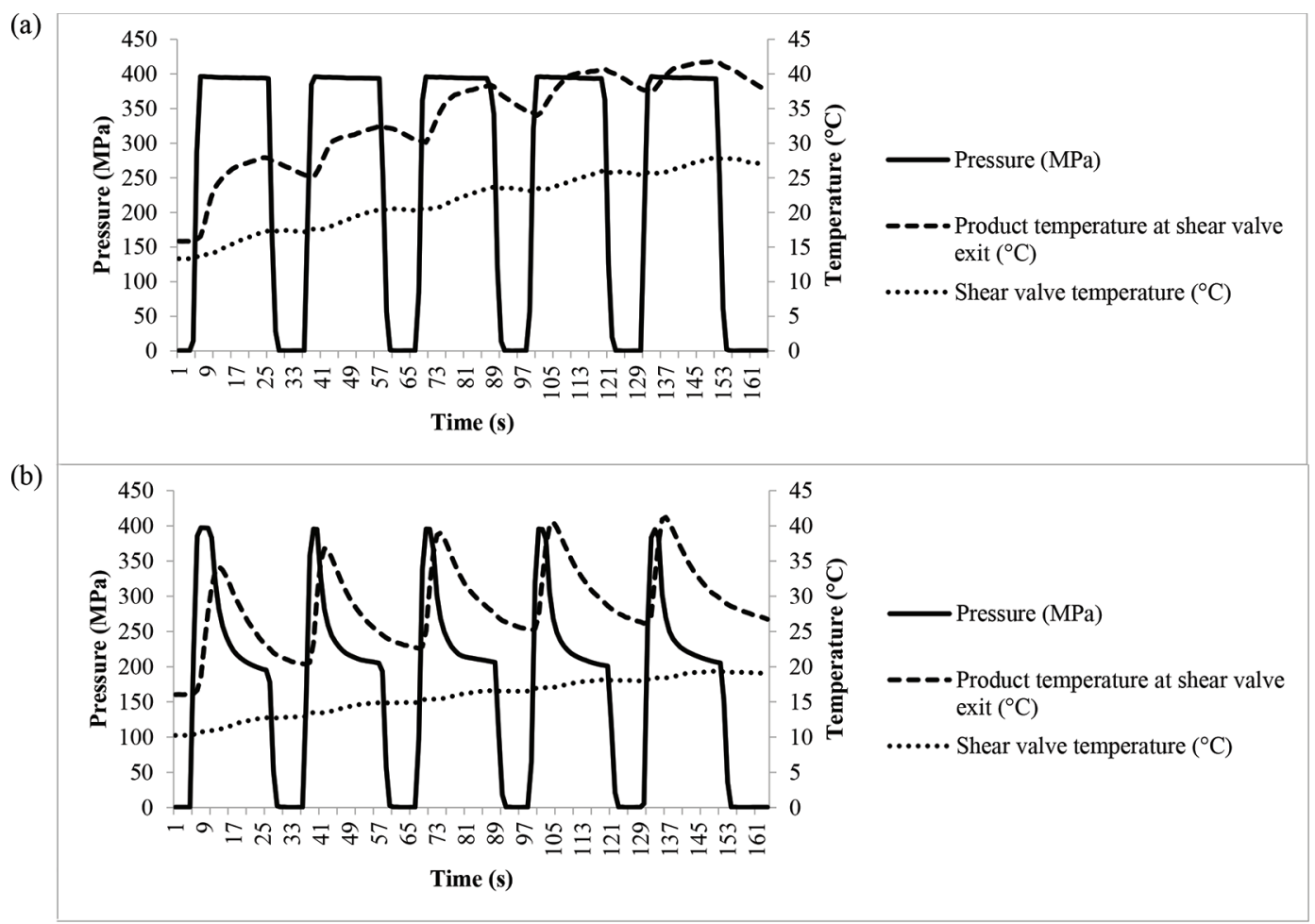

Figure 5. Pressure-temperature history during $35^{\circ} \mathrm{C}$ ultra-shear technology treatment for 5 process runs at (a) low flow rate and (b) high flow rate.

perature was achieved and appeared to reach a steady state from there on. During $65^{\circ} \mathrm{C}$ UST treatment, the maximum process temperature at the exit of shear valve at low- and high flow rates were $69.52 \pm 1.51^{\circ} \mathrm{C}$ and $65.48 \pm 1.53^{\circ} \mathrm{C}$, respectively. Samples for analysis were collected from $3 \mathrm{rd}$ through 10th process runs, so that samples were treated under designed process conditions. Assuming milk behaves as water does for initial temperatures of $25^{\circ} \mathrm{C}$ and $15^{\circ} \mathrm{C}$, the temperature rise as a consequence of shearing were theoretically estimated as $26.20^{\circ} \mathrm{C} / 100 \mathrm{MPa}$ and $26.25^{\circ} \mathrm{C} / 100 \mathrm{MPa}$, respectively. In the present study, apparent temperature rise in milk samples was 10.12 to $11.13^{\circ} \mathrm{C} / 100 \mathrm{MPa}$ during $65^{\circ} \mathrm{C}$ UST treatment, close to values in earlier studies (Thiebaud et al., 2003; Hayes and Kelly, 2003; Pereda et al., 2007; Martínez-Monteagudo et al., 2017). CortésMuñoz et al. (2009) attributed the difference between experimentation and theoretical calculation to heat loss as well as energy expended for particle size reduction.

\section{Pressure-Thermal History of $35^{\circ} \mathrm{C}$ UST-Treated Samples}

During UST treatment at $35^{\circ} \mathrm{C}$ (Figures 5a and $5 \mathrm{~b})$, the maximum process temperature attained during low- and high flow rates were $36.14 \pm 5.81^{\circ} \mathrm{C}$ and
$38.24 \pm 2.83^{\circ} \mathrm{C}$, respectively. The cooling pad acted as a heat sink and prevented excessive thermal exposure on product. At process temperature of $35^{\circ} \mathrm{C}$, the highest temperature rise per second of $8.90 \pm 3.32^{\circ} \mathrm{C} / \mathrm{s}$ for each process run was observed under high flow rate, due to the higher temperature difference between the shear valve body and product temperature. During $35^{\circ} \mathrm{C}$ UST experiments, samples were collected from second to fifth process runs. The treatment was restricted to 5 continuous process runs because the sample temperature increased beyond the process temperature after the fifth process run, due to cumulative addition of heat to the shear valve. It is worth noting that the temperature rise per second for each process run for $65^{\circ} \mathrm{C}$ and $35^{\circ} \mathrm{C}$ process temperature under high flow rate $(5.13$ $\pm 0.78^{\circ} \mathrm{C} / \mathrm{s}$ and $\left.8.90 \pm 3.32^{\circ} \mathrm{C} / \mathrm{s}\right)$ was higher than the low flow rate $\left(1.45 \pm 0.48^{\circ} \mathrm{C} / \mathrm{s}\right.$ and $\left.0.40 \pm 0.14^{\circ} \mathrm{C} / \mathrm{s}\right)$. The higher temperature during high flow rate could be attributed to higher power dissipation owing to larger clearance between valve seat and ball valve.

\section{Effect of Various Treatments on Milk Quality Attributes}

Milk Particle Size. The influence of pressure, shear, and temperature on the particle size parameters of raw 
milk is shown in Table 1. It was observed that the high pressure and subsequent shear in UST treatment caused significant reduction $(P<0.05)$ in the particle size. The UST-treated milk had an average particle diameter of $335.89 \mathrm{~nm}\left(65^{\circ} \mathrm{C}\right.$ UST $)$ and $291.45 \mathrm{~nm}\left(35^{\circ} \mathrm{C}\right.$ UST $)$ compared with diameter of $3,511.76 \mathrm{~nm}$ for raw milk samples. Within the experimental conditions, the temperature of UST treatment and magnitude of flow rates did not have significant effect on particle size reduction. Intense physical forces such as shear, turbulence, and elongation stress experienced by milk flowing through the shear valve likely facilitated the particle size reduction. In milk, the lipid portion takes the form of emulsified fat globules enwrapped by surface active milk fat globule membrane (MFGM), which maintains fat globule integrity and allows them to remain dispersed (Jiménez-Flores and Brisson, 2008). The physical forces caused disruption of MFGM and reduction of the fat globules size (Lopez et al., 2015).

The PDI of untreated milk was 0.420 , which indicated broad distribution of particles. Variations in fat globule size might favor destabilization and fat separation by Ostwald ripening and creaming (Cavazos-Garduño et al., 2016). The UST treatment decreased PDI values to between 0.246 and 0.233 (Table 1 ). The magnitude of flow rate or the process temperature during UST treatment did not significantly affect the PDI.

The volume-weighted mean diameter $\left(\mathrm{D}_{4,3}\right)$ and surface-weighted mean diameter $\left(D_{3,2}\right)$ of raw milk were 4,052.62 $\mathrm{nm}$ and $1,471.13 \mathrm{~nm}$, respectively. These diameters were similar to those reported by Tobin et al. (2015) for untreated raw milk $(4,500 \mathrm{~nm}$ and $1,000 \mathrm{~nm}$, respectively). The UST treatment at $35^{\circ} \mathrm{C}$ under low flow rate reduced these values to $557.02 \mathrm{~nm}$ and 403.71 $\mathrm{nm}$, respectively (Table 1). Thiebaud et al. (2003) reported slightly higher $\mathrm{D}_{4,3}$ and $\mathrm{D}_{3,2}$ values of 1,730 $\mathrm{nm}$ and $770 \mathrm{~nm}$, respectively, for milk with $14^{\circ} \mathrm{C}$ inlet temperature when processed at $300 \mathrm{MPa}$. This finding might be due to the different experimental apparatus (e.g., model FPG7400 H, Stansted Fluid Power Ltd., Essex, UK) used by Thiebaud et al. (2003), with different shear valve geometry. Earlier research reported that both $\mathrm{D}_{4,3}$ and $\mathrm{D}_{3,2}$ increase with increasing inlet temperatures (Pereda et al., 2007; Thiebaud et al., 2003; Amador-Espejo et al., 2014). Both $\mathrm{D}_{10}$ and $\mathrm{D}_{90}$ values reduced from 1,721.93 and 7,177.28 $\mathrm{nm}$ in untreated milk up to a minimum of 162.06 and $524.18 \mathrm{~nm}$, respectively, in UST treatment at $35^{\circ} \mathrm{C}$ under low flow rate (Table 1 ).

Studies have shown that above certain threshold pressures, the fat globules reaggregate after shear treatment over a period of time. This reaggregation may be due to coalescence of smaller particles into large fat sizes (Pereda et al., 2007; Amador-Espejo et al., 2014).




Martínez-Monteagudo et al. (2017) observed that the mean particle size of dairy beverages decreased with increasing pressure from 103 to $160 \mathrm{MPa}$ and gradually increased with increasing pressure from 160 to 288 $\mathrm{MPa}$, thus identifying the threshold pressure at 160 MPa. Earlier, Tornberg (1980) explained that higher intensity of homogenization or greater content of fat could cause coalescence and result in bigger fat globules. Therefore, the fat globule size immediately after shear might have been lesser than observed during analysis in the present study.

Thiebaud et al. (2003) and Datta et al. (2005) reported decreasing fat globule sizes upon homogenization at $200 \mathrm{MPa}$ with increasing outlet temperature. In the present study, the effect of process temperature in UST was insignificant. However, the lowest mean fat globule size of $291.45 \mathrm{~nm}$ was noted in UST treatment at $35^{\circ} \mathrm{C}$. This finding might emphasize the dominating influence of proteins rather than outlet temperature during UST on the fat globules size reduction. After shear treatment, the MFGM is disrupted and the new smaller fat globule created is covered by a new membrane formed by surface active components, the majority of them being casein micelles (Michalski and Januel, 2006). During UST treatment at $35^{\circ} \mathrm{C}$, proteins might have been left intact to cover and stabilize the fat globules.

Batch HPP did not cause significant change in the mean diameter of particles regardless of pressure holding time. This result is consistent with Huppertz et al. (2003) who reported little or no difference between the milk fat globule size in untreated milk and HPP-treated milk at pressures up to $600 \mathrm{MPa}$ at $20^{\circ} \mathrm{C}$ and pressure holding times up to $30 \mathrm{~min}$. Similar observations were reported by other researchers including Dumay et al. (1996), Ye et al. (2004), and Stratakos et al. (2019).

Thermal process at $72^{\circ} \mathrm{C}$ for $15 \mathrm{~s}$ caused slight reduction in the mean particle size up to $2,698.75 \mathrm{~nm}$ (Table 1). Michalski and Januel (2006) stated that heat treatment with no associated homogenization does not change the size of milk fat. On contrary, Stratakos et al. (2019) heat pasteurized raw milk samples at $72 \pm 0.5^{\circ} \mathrm{C}$ for $5 \mathrm{~min}$ and reported that pasteurized milk produced significantly $(P<0.05)$ smaller fat globules size $(0.32$ $\pm 0.01 \mu \mathrm{m})$ compared with untreated raw milk (1.60 $\pm 0.11 \mu \mathrm{m})$. This finding is consistent with the present study. Further, the PDI of milk treated by the thermal process in the present study was the highest at 0.491, which might be attributed to differently sized fat particles in the milk.

Particle Size Distribution. From Figures 6a and $6 \mathrm{~b}$, it can be observed that untreated milk showed a multimodal distribution, with 2 major peaks between 3,000 and 4,500 $\mathrm{nm}$ and a minor peak around $100 \mathrm{~nm}$.
Researchers reported major peak around 3,700 to 3,800 $\mathrm{nm}$ corresponding to fat globule and another peak around 100 to $200 \mathrm{~nm}$ corresponding to casein micelles in raw milk (Thiebaud et al., 2003; Amador-Espejo et al., 2014; Rodarte et al., 2018). The distribution is also wide, which corroborates the higher PDI (0.420) of the untreated milk samples and implies larger variations among particle sizes.

The UST treatment at temperatures of 65 and $35^{\circ} \mathrm{C}$ distinctly reduced particle size and shifted peaks toward left in mean diameter scale. The peak was transformed from multimodal and broad to unimodal and narrow distribution, corroborating the lesser PDI values (Table 1). Amador-Espejo et al. (2014) observed conversion from bimodal to monomodal distribution when $200 \mathrm{MPa}$ and initial temperatures ranging from 55 to $85^{\circ} \mathrm{C}$ were used to homogenize milk. Further, the unimodal distribution and absence of separate peak for casein indicated that UST disrupted the casein into smaller submicelles (Figure 6b). Earlier researches have reported that high pressure and shear action leads to the dissociation of casein to smaller submicelles (Roach and Harte, 2008; Chevalier-Lucia et al., 2011).

The pressure-treated (HPP) samples at $400 \mathrm{MPa}$ for 0 and 3 min showed multimodal and polydisperse distribution with the peaks observed at different diameter ranges. Although HPP for 0 min had a major peak similar to raw milk, HPP for 3 min had a major peak at a lesser diameter than raw milk (Figure 6a). This result can be attributed to disruption of fat globules and subsequent reaggregation of fat particles after HPP treatment (Pereda et al., 2007). These phenomena can be corroborated by presence of a tail after the first major peak in both 0 and 3 min HPP samples.

The distributions of 0 - and 3-min pressure holding times also indicated minor peaks at $\sim 450 \mathrm{~nm}$ and $\sim 100$ $\mathrm{nm}$ diameters, respectively, which could be contributed by casein micelles. Literatures suggest that HPP could enable both increase and decrease in casein micelles size and number due to disruption of casein micelle into submicelles by high pressure and the subsequent reassociation phenomena in samples at atmospheric pressure (Huppertz et al., 2006; Broyard and Gaucheron, 2015). Pressure of $250 \mathrm{MPa}$ could cause $\sim 30 \%$ increase in size of casein micelle and pressures above $300 \mathrm{MPa}$ could reduce the size by $\sim 50 \%$ (Huppertz et al., 2004; Goyal et al., 2018). The effect on milk protein is diverse, based on the different pressures and holding times (Huppertz et al., 2006; Cadesky et al., 2017). The observations indicate that the casein size reduction in UST-treated samples might be caused by shear rather than pressure alone.

The samples treated with thermal process at $72^{\circ} \mathrm{C}$ for 15 s showed multimodal and polydisperse distribution, 
but different than that from untreated milk. Two major peaks between 3,000 and 5,000 $\mathrm{nm}$ were noticed, which could be attributed to the fat globules of a different size range. A minor peak was noted around $150 \mathrm{~nm}$, which could be attributed to aggregated casein micelles (Figure 6b). Sauer and Moraru (2012) subjected micellar casein concentrates $(\mathbf{M C C})$ at $\mathrm{pH}<6.7$ to temperatures of 110 and $120^{\circ} \mathrm{C}$. The target temperatures were reached in $52 \mathrm{~s}$, and then the MCC was cooled immediately to $20^{\circ} \mathrm{C}$ by immersion in ice. It was observed that the casein micelles in MCC showed visibly stronger aggregation with increasing temperatures from 110 to $120^{\circ} \mathrm{C}$.

Zeta Potential. The zeta potential of untreated raw milk $(\mathrm{pH} 6.61 \pm 0.066)$ was $-47.90 \mathrm{mV}$ (Table 2 ). The values in our study were higher than values reported by other researchers $[-34.1 \mathrm{mV}$ in raw milk with 3.2 to $3.3 \%$ fat (Tunick et al., 2016) and -35.5
$\mathrm{mV}$ in Friesian cow raw milk (Gallier et al., 2012)]. The relatively higher zeta potential observed in the present study could be due to the composition of milk used, including higher fat content.

Thermally processed $\left(72^{\circ} \mathrm{C}\right.$ for $\left.15 \mathrm{~s}\right)$ samples had a zeta potential of $-51.66 \mathrm{mV}$ that was not significantly different from untreated milk. He et al. (2017) reported that the zeta potential of emulsions prepared with MFGM were only slightly altered by heat, with no significant changes with heat treatment at temperature of 35 to $85^{\circ} \mathrm{C}$ for $30 \mathrm{~min}$.

Zeta potential of HPP-treated samples at 0 and 3 min were $-48.23 \mathrm{mV}$ and $-48.74 \mathrm{mV}$, respectively. In the present study, similar to thermally treated samples, pressure-treated samples did not cause significant difference in zeta potential as compared with the untreated milk sample. This result might be due to dissociation of casein micelles upon compression by high pressure and


Figure 6. Volume-weighted differential particle size distribution of milk samples (A) from 0 to $10,000 \mathrm{~nm}$ and (B) from 0 to $1,400 \mathrm{~nm}$. HPP $=$ high-pressure processed; UST $=$ ultra-shear technology. ( indicates untreated raw milk; $\mathbf{\square}$ indicates thermal process-72 ${ }^{\circ} \mathrm{C}-15 \mathrm{~s} ; \boldsymbol{\Delta}$ indicates $\mathrm{HPP}-400 \mathrm{MPa}-40^{\circ} \mathrm{C}-0 \mathrm{~min}$ - indicates $\mathrm{HPP}-400 \mathrm{MPa}-40^{\circ} \mathrm{C}-3 \mathrm{~min} ; \times$ indicates UST-400 $\mathrm{MPa}-65^{\circ} \mathrm{C}-\mathrm{low}$ flow rate; $\bullet$ indicates $\mathrm{UST}-400 \mathrm{MPa}-$ $65^{\circ} \mathrm{C}$-high flow rate; + indicates UST-400 $\mathrm{MPa}-35^{\circ} \mathrm{C}$-low flow rate; $*$ indicates UST-400 $\mathrm{MPa}-35^{\circ} \mathrm{C}-\mathrm{high}$ flow rate.) 
reaggregation of casein micelles after depressurization (Broyard and Gaucheron, 2015).

The zeta potential of UST-treated samples varied from -36.36 to $-28.55 \mathrm{mV}$, which was significantly less than untreated $(P=0.001)$, HPP-treated, and thermally processed samples $(P<0.05)$. During UST treatment, MFGM is disrupted, and a new surface is created on which whey and casein proteins are adsorbed. The differences in casein on the MFGM could have influenced the zeta potential. Meena et al. (2016) homogenized ultra-filtered skim milk at $13.79 \mathrm{MPa}$ and $3.45 \mathrm{MPa}$ and reported zeta potential reduction due to surface modifications in milk protein because of shearing and cavitation. The different temperatures of UST treatment did not elicit significant variation in the zeta potential of samples, eliminating the temperature effect during UST in the studied range. It has been previously reported that magnitude of thermal effects did not significantly alter the zeta potential of milk (Darling and Dickson, 1979). In a similar manner, the magnitude of flow rates and the interaction of temperature and flow rate in UST treatment did not have any influence $(P=$ 0.138 ) on zeta potential. This finding might elucidate equivalent effect of shear in low- and high flow rates, despite the different temperature rise per second (Figures 4 and 5). These observations show the dominating effect of shear on the zeta potential, rather than the high pressure or temperature of UST treatment. Factors such as pH (Meena et al., 2016), casein hydration (Broyard and Gaucheron, 2015), and lipolytic products (Gallier et al., 2012) could also influence the zeta potential. All UST-treated samples exhibited high stability regarding the measured zeta potential, which reiterates the role of fat globule size reduction by high shear in stabilizing the milk against creaming.

$p H$. The $\mathrm{pH}$ of untreated raw milk was 6.61 (Table 2 ). The $\mathrm{pH}$ of samples treated using different processing techniques were not significantly different from untreated samples. In an earlier study, Pereda et al. (2007) homogenized milk with an inlet temperature of $30^{\circ} \mathrm{C}$ at $300 \mathrm{MPa}$ and observed constant $\mathrm{pH}$ until $18 \mathrm{~d}$ of storage at $4^{\circ} \mathrm{C}$.

Viscosity. The viscosity of untreated milk was 2.680 $\mathrm{mPa} \cdot \mathrm{s}$ (Table 2). Thermal processing at $72^{\circ} \mathrm{C}$ for $15 \mathrm{~s}$ produced samples with viscosity of $2.747 \mathrm{mPa} \cdot \mathrm{s}$, which was not significantly different from untreated milk and UST-treated samples. The viscosity of milk samples subjected to HPP for $0 \mathrm{~min}(3.053 \mathrm{mPa} \cdot \mathrm{s})$ was significantly $(P=0.03)$ higher than the untreated samples. Furthermore, viscosity of samples under HPP treatment for $3 \mathrm{~min}(3.083 \mathrm{mPa} \cdot \mathrm{s})$ were significantly higher than untreated $(P=0.017)$, UST-, and thermally treated samples, indicating the effect of holding time under pressure. Under high pressures above $300 \mathrm{MPa}$ and for pressure holding times over $15 \mathrm{~min}$ (Gaucheron et al., 1997; Needs et al., 2000), the casein micelles disintegrate into smaller particles, casein micelle hydration increases, and the viscosity of milk increases (Huppertz et al., 2002; Broyard and Gaucheron, 2015). In the present study, it was also noted that the HPP treatment at $400 \mathrm{MPa}$ for 3 min resulted in no creaming in samples, which might also be attributed to the casein micellar networking and increased viscosity. Viscosity of USTtreated samples varied from $2.710 \mathrm{mPa} \cdot \mathrm{s}$ for samples treated at high flow rate at $35^{\circ} \mathrm{C}$ to $2.970 \mathrm{mPa} \cdot \mathrm{s}$ for samples treated at high flow rate at $65^{\circ} \mathrm{C}$. It is interesting to note that viscosities of UST-treated samples at $35^{\circ} \mathrm{C}$ were not significantly different from untreated samples, which might mean that the viscosity increase by HPP was negated by UST through reduction of particle size and protein retention. The temperatures and flow rate interactions in UST treatment did not have significant effect on the viscosity of samples.

Creaming. The creaming of processed milk samples as compared with untreated milk during $15 \mathrm{~d}$ of refrigerated storage is shown in Figure 7. The creaming of untreated milk showed a rapid increase from 0 to $1.5 \mathrm{~mL} / 10 \mathrm{~mL}$ milk in the first $24 \mathrm{~h}$ and subsequently leveled off at $1 \mathrm{~mL} / 10 \mathrm{~mL}$ until $15 \mathrm{~d}$. Stokes' law states that the velocity of creaming in milk is correlated di-

Table 2. Zeta potential, $\mathrm{pH}$, and viscosity of milk samples ${ }^{1}$

\begin{tabular}{|c|c|c|c|c|}
\hline No. & Treatment $^{2}$ & Zeta potential $(\mathrm{mV})$ & $\mathrm{pH}$ & Viscosity $(\mathrm{mPa} \cdot \mathrm{s})$ \\
\hline 1 & Untreated raw milk & $-47.90^{\mathrm{a}} \pm 1.66$ & $6.61^{\mathrm{ab}} \pm 0.066$ & $2.680^{\mathrm{a}} \pm 0.24$ \\
\hline 2 & Thermal process, $72^{\circ} \mathrm{C}, 15 \mathrm{~s}$ & $-51.66^{\mathrm{a}} \pm 1.76$ & $6.64^{\mathrm{ab}} \pm 0.006$ & $2.747^{\mathrm{ab}} \pm 0.19$ \\
\hline 3 & $\mathrm{HPP}, 400 \mathrm{MPa}, 40^{\circ} \mathrm{C}, 0 \mathrm{~min}$ & $-48.23^{\mathrm{a}} \pm 3.68$ & $6.57^{\mathrm{a}} \pm 0.006$ & $3.053^{\mathrm{c}} \pm 0.08$ \\
\hline 4 & $\mathrm{HPP}, 400 \mathrm{MPa}, 40^{\circ} \mathrm{C}, 3 \mathrm{~min}$ & $-48.74^{\mathrm{a}} \pm 1.98$ & $6.64^{\mathrm{ab}} \pm 0.006$ & $3.083^{\mathrm{c}} \pm 0.07$ \\
\hline 5 & UST, $400 \mathrm{MPa}, 65^{\circ} \mathrm{C}$, low flow rate & $-33.81^{\mathrm{b}} \pm 2.35$ & $6.66^{\mathrm{b}} \pm 0.012$ & $2.920^{\mathrm{bc}} \pm 0.07$ \\
\hline 6 & UST, $400 \mathrm{MPa}, 65^{\circ} \mathrm{C}$, high flow rate & $-36.36^{\mathrm{b}} \pm 1.37$ & $6.66^{\mathrm{b}} \pm 0.00$ & $2.970^{\mathrm{c}} \pm 0.01$ \\
\hline 7 & $\mathrm{UST}, 400 \mathrm{MPa}, 35^{\circ} \mathrm{C}$, low flow rate & $-33.09^{\mathrm{b}} \pm 6.72$ & $6.59^{\mathrm{ab}} \pm 0.035$ & $2.740^{\mathrm{ab}} \pm 0.04$ \\
\hline 8 & $\mathrm{UST}, 400 \mathrm{MPa}, 35^{\circ} \mathrm{C}$, high flow rate & $-28.55^{\mathrm{b}} \pm 1.82$ & $6.61^{\mathrm{ab}} \pm 0.015$ & $2.713^{\mathrm{ab}} \pm 0.06$ \\
\hline
\end{tabular}

${ }^{\mathrm{a}-\mathrm{c}}$ Mean values without common superscripts in same column are significantly different $(P<0.05)$.

${ }^{1}$ Values are expressed as mean $\pm \mathrm{SD}$.

${ }^{2} \mathrm{HPP}=$ high-pressure processed; UST = ultra-shear technology. 




Figure 7. Creaming of milk samples. Data points of all ultra-shear technology-treated samples were identical and therefore the symbols are overlaid. HPP = high-pressure processed; UST = ultra-shear technology. (- indicates untreated raw milk; $\boldsymbol{\square}$ indicates thermal process-72 ${ }^{\circ} \mathrm{C}-15 \mathrm{~s}$; $\Delta$ indicates HPP-400 MPa-40 $\mathrm{C}-0 \mathrm{~min} ;$ indicates $\mathrm{HPP}-400 \mathrm{MPa}-40^{\circ} \mathrm{C}-3 \mathrm{~min} ; \times$ indicates UST-400 MPa- $65^{\circ} \mathrm{C}-\mathrm{low}$ flow rate; $\bullet$ indicates UST$400 \mathrm{MPa}-65^{\circ} \mathrm{C}$-high flow rate; + indicates UST-400 $\mathrm{MPa}-35^{\circ} \mathrm{C}$-low flow rate; ${ }^{*}$ indicates UST-400 $\mathrm{MPa}-35^{\circ} \mathrm{C}$-high flow rate.) Values are means obtained from 3 replicate samples from independent process runs; vertical error bars represent $\pm \mathrm{SD}$.

rectly to fat globule size and inversely to viscosity of the dispersed phase. Large fat globules or clusters are more sensitive to creaming effect (Walstra and Jenness, 1984).

The UST-treated samples with smaller particle sizes (Table 1) exhibited no creaming during the studied period. Process temperature and flow rates during UST treatment did not have significant influence on the creaming of samples. Significant reduction in particle size during UST treatment reduced the velocity of fat by multiple degrees and made samples stable. This result is consistent with the earlier observation by Pereda et al. (2007) who exposed fresh raw bovine milk to high-pressure homogenization and reported no creaming in treated milks during refrigerated storage.

Pressure-treated samples at $400 \mathrm{MPa}$ for 0 min showed excessive creaming compared with untreated milk. Such samples showed rapid increase in cream volume up to $3.17 \mathrm{~mL} / 10 \mathrm{~mL}$ in $24 \mathrm{~h}$ and subsequent leveling off at $2.67 \mathrm{~mL} / 10 \mathrm{~mL}$ throughout the storage period (Figure 7). Huppertz et al. (2003) reported a $20 \%$ increase in cream volume as compared with untreated milk when treated at $400 \mathrm{MPa}$ at $20^{\circ} \mathrm{C}$ for $0 \mathrm{~min}$. The increased creaming might be defined by different mechanisms. HPP might have caused aggregation of lipoproteins in the MFGM (Kanno et al., 1998) resulting in clustering of milk fat (Huppertz et al., 2003). Huppertz et al., (2003) noted that the lipoproteins of serum portion of milk, called skim milk membrane (SMM), could have associated with the MFGM and/or SMM materials, which might have created SMM networks and facili- tated formation of larger milk fat clusters, increasing creaming.

In contrast, pressure treatment at $400 \mathrm{MPa}$ for $3 \mathrm{~min}$ did not cause creaming in samples during the studied period. Pressure treatment at above $400 \mathrm{MPa}$ at 20 to $50^{\circ} \mathrm{C}$ for 5 - to 30 -min hold times causes denaturation of IgM, which influences its ability to bind with milk fat or SMM and inhibits clustering of fat (Felipe et al., 1997; Huppertz et al., 2003). Further, such treatment might cause disruption of casein micelles, formation of casein aggregates, and protein solubilization to increase the protein associated with fat globules and milk viscosity, thus decreasing creaming (Gervilla et al., 2001; Huppertz et al., 2003, 2011).

Thermal processing at $72^{\circ} \mathrm{C}$ for $15 \mathrm{~s}$ resulted in cream volume of $0.5 \mathrm{~mL} / 10 \mathrm{~mL}$ milk in samples throughout storage. It was reported that heating milk above $70^{\circ} \mathrm{C}$ would presumably denature IgM and reduce creaming considerably (Rowland, 1937). But individual fat globules can rise to the top and exhibit some creaming, because the fat is not homogenized (Huppertz et al., 2003). Pereda et al. (2007) pasteurized raw bovine milk at $90^{\circ} \mathrm{C}$ for $15 \mathrm{~s}$ and observed creaming of $<1 \mathrm{~mL} / 100$ $\mathrm{mL}$ during refrigerated storage.

Lipase Activity. The relative lipase activity of UST- and HPP-treated milk samples as compared with untreated milk $(100 \%)$ is shown in Figure 8. The pressure and subsequent shear action facilitated significant reduction $(P<0.05)$ in lipase activity as compared with untreated and batch-pressure-treated milk. After $65^{\circ} \mathrm{C}$ UST treatment at low- and high flow rates, the 
relative lipase activities of samples were $56.63 \pm 3.29$ and $60.60 \pm 6.36 \%$, respectively, with no significant difference caused by flow rate. Datta et al. (2005) treated raw whole milk with high-pressure homogenization of milk at $200 \mathrm{MPa}$ and increasing outlet temperature from 56 to $80^{\circ} \mathrm{C}$ and reported greater inactivation of lipase activity at higher outlet temperature with total inactivation happening at temperatures over $71^{\circ} \mathrm{C}$.

The relative lipase activities of milk samples UST treated at $35^{\circ} \mathrm{C}$ at low- and high flow rates were 29.93 \pm 9.21 and $31.01 \pm 6.93 \%$, respectively, with no significant difference caused by flow rate. The lipase activities of $35^{\circ} \mathrm{C}$ UST-treated samples were significantly $(P<$ $0.05)$ less than untreated, HPP-treated, and $65^{\circ} \mathrm{C}$ USTtreated milk. This finding indicated the dominant role of thermal effects of UST treatment on lipase activity. In earlier studies where homogenization was performed at lesser pressures of $200 \mathrm{MPa}$ (Datta et al., 2005) and $17 \mathrm{MPa}$ (Wiking and Dickow, 2013), the lipase activity was observed to be reduced by increasing temperature. In the present study conducted at $400 \mathrm{MPa}$, the lipase activity of samples UST treated at $35^{\circ} \mathrm{C}$ were lesser than $65^{\circ} \mathrm{C}$ UST-treated samples. It is worth noting that, for UST treatment at $35^{\circ} \mathrm{C}$, the initial temperature of milk was $\sim 15^{\circ} \mathrm{C}$. The lower initial and process temperatures might have led to relatively less lipase activity. Jandal (1996) reported that cooling caused a decrease in lipase activity in cow milk $\left(3.22 \mu\right.$ eqmL ${ }^{-1}$ $\mathrm{h}^{-1}$ ) and a temperature range of 20 to $50^{\circ} \mathrm{C}$ had only slight influence on lipase activity.

The lipase activity of HPP-treated milk at $400 \mathrm{MPa}$ for 0 and $3 \mathrm{~min}$ were $103.14 \pm 10.36$ and $114.75 \pm$
$8.92 \%$, respectively. Although activity of pressure comeup time (0 min holding) did not significantly differ from untreated milk, the pressure holding of 3 min showed significant $(P=0.029)$ increase over untreated milk. The result indicated the effect of increased hold time under isostatic pressure on lipase activity. This finding is consistent with Pandey and Ramaswamy (2004) who observed that exposure of raw milk to $400 \mathrm{MPa}$ $\left(\right.$ at $3{ }^{\circ} \mathrm{C}$ ) for no hold time showed an enhancing effect (100\%) on lipase and the activity continued increasing with increasing hold time up to $20 \mathrm{~min}$ (Pandey and Ramaswamy, 2004).

Lipase is generally unstable to heat treatment (Deeth, 2006). Several researchers have documented that the thermal pasteurization process at $72^{\circ} \mathrm{C}$ for 15 $\mathrm{s}$ can inactivate lipase activity in milk with no or little residual activity (Chandan and Shahani, 1964; Jandal, 1996; Pandey and Ramaswamy, 2004; Deeth, 2006).

It should be noted that lipase was baroresistant (400 $\mathrm{MPa}$ at $\sim 40^{\circ} \mathrm{C}$ ) and the activity further enhanced with increased pressure hold time. However, the shear treatment following the pressure in UST reduced the lipase activity, with reduced activity at a modest process temperature of $35^{\circ} \mathrm{C}$.

$S D S-P A G E$. The changes to the composition of protein fractions in batch HPP- and UST-treated samples as compared with untreated samples was obtained by SDS-PAGE electrophoresis (Figure 9). Highpressure processing at $400 \mathrm{MPa}, \sim 40^{\circ} \mathrm{C}$, at 0 and 3 min hold times had least effect on casein protein fractions of milk samples (Figure 9a). However, the HPP treatment had marked effect on the major whey protein



Figure 8. Relative lipase activity of milk samples. HPP = high-pressure processing; UST = ultra-shear technology. Error bars represent $\pm \mathrm{SD}$ of 3 replicate samples obtained from 3 independent process runs. Labels (a, b, c, and d) above the bars represent statistically significant difference among different treatments $(P<0.05)$. 
$\beta$-lactoglobulin, with the effect more pronounced for 3 min holding time, as evident by the relatively lesser band intensity. Earlier reports suggest higher sensitivity of $\beta$-lactoglobulin to high pressure due to the presence of a free sulfhydryl group and higher resistance of $\alpha$-lactalbumin to high pressures due to rigid molecular structure and the lack of free sulfhydryl groups (Huppertz et al., 2004). High pressure of $400 \mathrm{MPa}$ at $\sim 20^{\circ} \mathrm{C}$ results in around 70 to $80 \%$ denaturation of $\beta$-lactoglobulin with the degree increasing with increasing hold time (Scollard et al., 2000; Huppertz et al., 2004). In contrast, $\alpha$-lactalbumin in raw milk resists denaturation up to $500 \mathrm{MPa}$ pressure (Garía-Risco et al., 2000). The casein protein fractions appeared to be less influenced under HPP conditions used in the present study. Huppertz et al. (2004) reported that casein micelles are disrupted by pressurization due to solubilization of micellar calcium phosphate and subsequently the casein particles are re-associated upon depressurization. Authors also noted that reassociation might not happen above certain threshold conditions (i.e, pressure $>300 \mathrm{MPa}$ for $30 \mathrm{~min}$; Huppertz et al., 2004).

Figures $9 \mathrm{~b}$ and $9 \mathrm{c}$ show the gel patterns of USTtreated samples at $65^{\circ} \mathrm{C}$ and $35^{\circ} \mathrm{C}$, respectively, at different flow rates. When comparing the gel patterns, some interesting differences were observed. In the USTtreated samples at $65^{\circ} \mathrm{C}$, the bands of whey proteins; namely, $\alpha$-lactalbumin and $\beta$-lactoglobulin, indicated denaturation as compared with untreated milk. Further, higher molecular weight protein aggregates were noted at the topmost band of gels in $65^{\circ} \mathrm{C}$ UST-treated samples, corroborating the observation. The denatur-

(a)

(1) (2) (3)

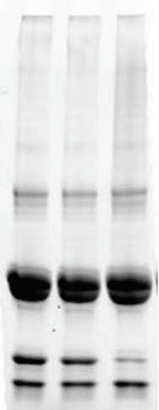

(1) Untreated raw milk
(2) $\mathrm{HPP}-400 \mathrm{MPa}-40{ }^{\circ} \mathrm{C}-0$
$\min$
(3) $\mathrm{HPP}-400 \mathrm{MPa}-40{ }^{\circ} \mathrm{C}-3$
min (b)

(1) (2) (3)



(1) Untreated raw milk (2) UST $-400 \mathrm{MPa}-65^{\circ} \mathrm{C}-$ Low flow rate (3) UST- $-400 \mathrm{MPa}-65^{\circ} \mathrm{C}-$ High flow rate ation of proteins might be due to the interactive effects of heat, pressure, and shear in UST treatment (Desrumaux and Marcand, 2002; Hayes et al., 2005).

On the other hand, in the UST-treated samples at $35^{\circ} \mathrm{C}$, the gel pattern and absence of high molecular weight protein aggregates on top indicated less denaturation in protein fractions (Figure 9c). Removal of thermal effect during $35^{\circ} \mathrm{C}$ UST treatment by cooling might have minimized protein changes. This effect was also corroborated by the occurrence of more proteins in the supernatant of $35^{\circ} \mathrm{C}$ UST-treated samples (Figure 10).

Protein Aggregation in UST-Treated Samples. The amount of aggregated protein in the UST-treated samples at $65^{\circ} \mathrm{C}$ and $35^{\circ} \mathrm{C}$ as compared with untreated samples are shown in Figure 10. Although untreated milk had $0.927 \%$ protein, UST treatment had lesser proteins in the supernatant, indicating relatively higher whey protein denaturation in these samples. It was also interesting to note that samples after $65^{\circ} \mathrm{C}$ UST treatment showed higher denaturation of whey proteins than samples after $35^{\circ} \mathrm{C}$ UST treatment. Under $35^{\circ} \mathrm{C}$ UST treatment at high flow rate the supernatant protein $(0.78 \%)$ was not significantly different from the untreated sample. Interestingly, the viscosity of $65^{\circ} \mathrm{C}$ UST-treated samples were slightly higher than $35^{\circ} \mathrm{C}$ UST-treated samples, which could be attributed to higher whey protein denaturation at higher temperatures (Table 2). Li et al. (2018) observed increased denatured whey protein in ultrapasteurized milk $\left(140^{\circ} \mathrm{C} / 2.3\right.$ s) as compared with HTST milk $\left(78^{\circ} \mathrm{C} / 15 \mathrm{~s}\right)$ and the aggregates formed by denatured proteins resulted in increased viscosity in ultrapasteurized milk samples. This

(c) (1) (2) (3)



(1) Untreated raw milk

(2) UST-400 MPa $-35^{\circ} \mathrm{C}-$

Low flow rate

(3) UST-400 MPa $-35^{\circ} \mathrm{C}-$

High flow rate

Figure 9. SDS-PAGE analysis of milk samples (the protein fractions are segregated as per molecular weight of the proteins and labeled). $\mathrm{HPP}=$ high-pressure processing; UST $=$ ultra-shear technology. 




Figure 10. Protein in the supernatant of milk samples. UST $=$ ultra-shear technology. Error bars represent $\pm \mathrm{SD}$ of 3 replicate samples obtained from 3 independent process runs. Labels (a, b, and c) above the bars represent statistically significant difference among different treatments $(P<0.05)$.

indicated that when the temperature of UST treatment is lesser, the degree of protein denaturation and viscosity in milk could be lesser.

\section{CONCLUSIONS}

The pressure-only treatment did not reduce particle size and seemingly increased the viscosity, creaming, and lipase activity of samples as compared with untreated milk. The thermal-only treatment provided a slight reduction in particle size and creaming in milk. The UST treatment, which involved high pressure and subsequent shear action performed at 65 and $35^{\circ} \mathrm{C}$, facilitated particle size reduction and eliminated creaming in samples. Within the experimental conditions, process temperature did not have any effect on particle size, zeta potential, viscosity, creaming, or $\mathrm{pH}$. However, UST temperature had marked effect on lipase activity and proteins, with $35^{\circ} \mathrm{C}$ retaining better protein quality and reducing greater lipase enzyme activity. Therefore, use of milder process temperature in UST is desired for the preservation of milk quality attributes. The flow rates, despite producing different rates of temperature rise, did not exhibit significant difference on most quality attributes studied. This finding could allow flexibility in designing crucial components such as shear valves for dairy beverages. Further, the physical changes and resulting chemical changes at the molecular level, including sensorial and nutritional changes, due to UST need to be studied. The findings revealed the differential effect of pressure, shear, temperature, and their interactions during UST treatment on raw milk quality. This information would be valuable for equipment providers to design shear valves taking into consideration the effect of treatment intensity on the product matrix. By suitable choice of pressure and thermal intensity, UST will also serve as a tool for food processors in introducing homogenized value-added pasteurized or shelf-stable milk protein beverages desired by consumers.

\section{ACKNOWLEDGMENTS}

Research was conducted at The Ohio State University Food Safety Engineering Laboratory, Center for Clean Food Process Technology Development (u.osu.edu/ foodsafetyeng/) and Parker Endowed Chair Laboratory in Dairy Foods (The Ohio State University, Columbus, $\mathrm{OH})$. The authors thank Israel Garcia Cano (Department of Food Science and Technology, The Ohio State University, Columbus, $\mathrm{OH}$ ) for his kind assistance in performing lipase activity analysis. Authors gratefully acknowledge the financial support for the study USDA NIFA grant 2018-67017-27914. References to commercial products or trade names are made with the understanding that no endorsement or discrimination by The Ohio State University is implied. The authors have not stated any conflicts of interest.

\section{REFERENCES}

Amador-Espejo, G. G., A. Suàrez-Berencia, B. Juan, M. E. Bárcenas, and A. J. Trujillo. 2014. Effect of moderate inlet temperatures in ultra-high-pressure homogenization treatments on physicochemical and sensory characteristics of milk. J. Dairy Sci. 97:659-671. https://doi.org/10.3168/jds.2013-7245.

Balasubramaniam, V. M., G. V. Barbosa-Cánovas, and H. L. Lelieveld. 2016. High-pressure processing equipment for the food industry. Pages 39-65 in High Pressure Processing of Food: Principles, Technology and Applications. V. M. Balasubramaniam, G. V. BarbosaCánovas, and H. L. Lelieveld, ed. Springer, New York, NY.

Instruments, B. 2020. Particle solutions software. Accessed Nov. 24, 2020. https://www.brookhaveninstruments.com/product/particle -solutions-software/.

Broyard, C., and F. Gaucheron. 2015. Modifications of structures and functions of caseins: A scientific and technological challenge. Dairy Sci. Technol. 95:831-862. https://doi.org/10.1007/s13594-015 -0220-y.

Cadesky, L., M. Walkling-Ribeiro, K. T. Kriner, M. V. Karwe, and C. I. Moraru. 2017. Structural changes induced by high-pressure processing in micellar casein and milk protein concentrates. J. Dairy Sci. 100:7055-7070. https://doi.org/10.3168/jds.2016-12072.

Cavazos-Garduño, A., J. C. Serrano-Niño, J. R. Solís-Pacheco, J. A. Gutierrez-Padilla, O. González-Reynoso, H. S. García, and B. R. Aguilar-Uscanga. 2016. Effect of pasteurization, freeze-drying and spray drying on the fat globule and lipid profile of human milk. J. Food Nutr. Res. 4:296-302.

Chandan, R. C., and K. M. Shahani. 1964. Milk lipases. A review. J. Dairy Sci. 47:471-480. https://doi.org/10.3168/jds.S0022 $-0302(64) 88694-X$.

Chevalier-Lucia, D., C. Blayo, A. Gràcia-Julià, L. Picart-Palmade, and E. Dumay. 2011. Processing of phosphocasein dispersions by dynamic high pressure: Effects on the dispersion physico-chemical characteristics and the binding of $\alpha$-tocopherol acetate to casein micelles. Innov. Food Sci. Emerg. Technol. 12:416-425. https://doi .org/10.1016/j.ifset.2011.07.007. 
Cortés-Muñoz, M., D. Chevalier-Lucia, and E. Dumay. 2009. Characteristics of submicron emulsions prepared by ultra-high pressure homogenisation: Effect of chilled or frozen storage. Food Hydrocoll. 23:640-654. https://doi.org/10.1016/j.foodhyd.2008.07.023.

Darling, D. F., and J. Dickson. 1979. The determination of the zeta potential of casein micelles. J. Dairy Res. 46:329-332. https://doi .org/10.1017/S0022029900017258

Datta, N., M. G. Hayes, H. C. Deeth, and A. L. Kelly. 2005. Significance of frictional heating for effects of high pressure homogenisation on milk. J. Dairy Res. 72:393-399. https://doi.org/10.1017/ S0022029905001056.

Deeth, H. C. 2006. Lipoprotein lipase and lipolysis in milk. Int. Dairy J. 16:555-562. https://doi.org/10.1016/j.idairyj.2005.08.011.

Desrumaux, A., and J. Marcand. 2002. Formation of sunflower oil emulsions stabilized by whey proteins with high-pressure homogenization (up to $350 \mathrm{MPa}$ ): Effect of pressure on emulsion characteristics. Int. J. Food Sci. Technol. 37:263-269. https://doi.org/10 .1046/j.1365-2621.2002.00565.x.

Dhakal, S., M. M. Giusti, and V. M. Balasubramaniam. 2016. Effect of high pressure processing on dispersive and aggregative properties of almond milk. J. Sci. Food Agric. 96:3821-3830. https://doi.org/ $10.1002 /$ jsfa. 7576 .

Diels, A. M. J., and C. W. Michiels. 2006. High-pressure homogenization as a non-thermal technique for the inactivation of microorganisms. Crit. Rev. Microbiol. 32:201-216. https://doi.org/10.1080/ 10408410601023516.

Dumay, E., C. Lambert, S. Funtenberger, and J. C. Cheftel. 1996. Effects of high pressure on the physico-chemical characteristics of dairy creams and model oil/water emulsions. LWT Food Sci. Technol. 29:606-625. https://doi.org/10.1006/fstl.1996.0094.

Felipe, X., M. Capellas, and A. J. R. Law. 1997. Comparison of the effects of high-pressure treatments and heat pasteurization on the whey proteins in goat's milk. J. Agric. Food Chem. 45:627-631. https://doi.org/10.1021/jf960406o.

Gallier, S., A. Ye, and H. Singh. 2012. Structural changes of bovine milk fat globules during in vitro digestion. J. Dairy Sci. 95:35793592. https://doi.org/10.3168/jds.2011-5223.

Garía-Risco, M. R., A. Olano, M. Ramos, R. López-Fandiño; Influence in the proteolytic activity and organoleptic properties of milk. 2000. Micellar changes induced by high pressure. Influence in the proteolytic activity and organoleptic properties of milk. J. Dairy Sci. 83:2184-2189. https://doi.org/10.3168/jds.S0022 -0302(00)75101-0.

Gaucheron, F., M. H. Famelart, F. Mariette, K. Raulot, F. Michela, and Y. Le Graeta. 1997. Combined effects of temperature and high-pressure treatments on physicochemical characteristics of skim milk. Food Chem. 59:439-447. https://doi.org/10.1016/ S0308-8146(96)00301-9.

Gervilla, R., V. Ferragut, and B. Guamis. 2001. High hydrostatic pressure effects on color and milk-fat globule of ewe's milk. J. Food Sci. 66:880-885. https://doi.org/10.1111/j.1365-2621.2001.tb15190.x.

Goyal, A., V. Sharma, N. Upadhyay, M. Sihag, and R. Kaushik. 2018. High pressure processing and its impact on milk proteins: A review. Res. Rev. J. Dairy Sci. Technol. 2:12-20.

Hayes, M. G., P. F. Fox, and A. L. Kelly. 2005. Potential applications of high pressure homogenisation in processing of liquid milk. J. Dairy Res. 72:25-33. https://doi.org/10.1017/S0022029904000524.

Hayes, M. G., and A. L. Kelly. 2003. High pressure homogenisation of raw whole bovine milk (a) effects on fat globule size and other properties. J. Dairy Res. 70:297-305. https://doi.org/10.1017/ S0022029903006320.

He, S., H. Tang, H. Yi, W. Xu, Y. Ma, and R. Wang. 2017. Properties of emulsions from milk fat globule membrane and its components. Int. J. Food Prop. 20:1342-1353. https://doi.org/10.1080/ 10942912.2017.1343348.

Humbert, G., M.-F. Guingamp, and G. Linden. 1997. Method for the measurement of lipase activity in milk. J. Dairy Res. 64:465-469. https://doi.org/10.1017/S0022029997002288.

Huppertz, T., P. F. Fox, and A. L. Kelly. 2003. High pressure-induced changes in the creaming properties of bovine milk. Innov. Food
Sci. Emerg. Technol. 4:349-359. https://doi.org/10.1016/S1466 $-8564(03) 00057-2$.

Huppertz, T., P. F. Fox, and A. L. Kelly. 2004. High pressure treatment of bovine milk: effects on casein micelles and whey proteins. J. Dairy Res. 71:97-106. https://doi.org/10.1017/S002202990300640X.

Huppertz, T., A. L. Kelly, and C. G. de Kruif. 2006. Disruption and reassociation of casein micelles under high pressure. J. Dairy Res. 73:294-298. https://doi.org/10.1017/S0022029906001725.

Huppertz, T., A. L. Kelly, and P. F. Fox. 2002. Effects of high pressure on constituents and properties of milk. Int. Dairy J. 12:561-572. https://doi.org/10.1016/S0958-6946(02)00045-6.

Huppertz, T., M. A. Smiddy, H. D. Goff, and A. L. Kelly. 2011. Effects of high pressure treatment of mix on ice cream manufacture. Int. Dairy J. 21:718-726. https://doi.org/10.1016/j.idairyj.2010.12 .005 .

Jandal, J. M. 1996. Effects of some thermal, chemical and mechanical treatments on lipase activity in Shammi goat milk. Small Rumin. Res. 20:275-279. https://doi.org/10.1016/0921-4488(95)00806-3.

Jiménez-Flores, R., and G. Brisson. 2008. The milk fat globule membrane as an ingredient: why, how, when? Dairy Sci. Technol. 88:518. https://doi.org/10.1051/dst:2007005.

Kanno, C., T. Uchimura, T. Hagiwara, M. Ametani, and N. Azuma. 1998. Effect of hydrostatic pressure on the physicochemical properties of bovine milk fat globules and the milk fat globule membrane. Pages 182-192 in High Pressure Food Science, Bioscience and Chemistry. N. S. Isaacs, ed. The Royal Society of Chemistry, Cambridge, UK.

Khalil, H., and R. Villota. 1988. Comparative study on injury and recovery of Staphylococcus aureus using microwaves and conventional heating. J. Food Prot. 51:181-186. https://doi.org/10.4315/0362 $-028 \mathrm{X}-51.3 .181$

Lee, Y.-H. 1992. Food-processing approaches to altering allergenic potential of milk-based formula. J. Pediatr. 121:S47-S50. https://doi .org/10.1016/S0022-3476(05)81406-4.

Li, Y., H. S. Joyner, B. G. Carter, and M. A. Drake. 2018. Effects of fat content, pasteurization method, homogenization pressure, and storage time on the mechanical and sensory properties of bovine milk. J. Dairy Sci. 101:2941-2955. https://doi.org/10.3168/ jds.2017-13568.

Linden, G., G. M. Humbert, R. Kouomegne, and M. F. Guingamp. 1991. Reagent for rendering biological media transparent and its analytical applications. Universite De Nancy I, assignee. US Pat. No. 4,981,610.

Lopez, C., C. Cauty, and F. Guyomarc'h. 2015. Organization of lipids in milks, infant milk formulas and various dairy products: Role of technological processes and potential impacts. Dairy Sci. Technol. 95:863-893. https://doi.org/10.1007/s13594-015-0263-0.

Marciniak, A., S. Suwal, M. Britten, Y. Pouliot, and A. Doyen. 2018. The use of high hydrostatic pressure to modulate milk protein interactions for the production of an alpha-lactalbumin enrichedfraction. Green Chem. 20:515-524. https://doi.org/10.1039/ C7GC03428H.

Maresca, P., F. Donsì, and G. Ferrari. 2011. Application of a multipass high-pressure homogenization treatment for the pasteurization of fruit juices. J. Food Eng. 104:364-372. https://doi.org/10 .1016/j.jfoodeng.2010.12.030.

Martínez-Monteagudo, S. I., S. Kamat, N. Patel, G. Konuklar, N. Rangavajla, and V. M. Balasubramaniam. 2017. Improvements in emulsion stability of dairy beverages treated by high pressure homogenization: A pilot-scale feasibility study. J. Food Eng. 193:4252. https://doi.org/10.1016/j.jfoodeng.2016.08.011.

Martínez-Monteagudo, S. I., B. Yan, and V. M. Balasubramaniam. 2017. Engineering process characterization of high-pressure homogenization - from laboratory to industrial scale. Food Eng. Rev. 9:143-169. https://doi.org/10.1007/s12393-016-9151-5.

Matsumiya, K., S. Horiguchi, T. Kosugi, T.-A. Mutoh, Y. Nambu, K. Nishimura, and Y. Matsumura. 2017. Effects of heat treatment and homogenization on milk fat globules and proteins in whipping creams. Food Struct. 12:94-102. https://doi.org/10.1016/j.foostr .2017.02.003. 
Meena, G. S., A. K. Singh, S. Borad, and N. R. Panjagari. 2016. Effect of concentration, homogenization and stabilizing salts on heat stability and rheological properties of cow skim milk ultrafiltered retentate. J. Food Sci. Technol. 53:3960-3968. https://doi.org/10 .1007/s13197-016-2388-4.

Michalski, M. C., and C. Januel. 2006. Does homogenization affect the human health properties of cow's milk? Trends Food Sci. Technol. 17:423-437. https://doi.org/10.1016/j.tifs.2006.02.004.

Needs, E. C., R. A. Stenning, A. L. Gill, V. Ferragut, and G. T. Rich. 2000. High-pressure treatment of milk: effects on casein micelle structure and on enzymic coagulation. J. Dairy Res. 67:31-42. https://doi.org/10.1017/S0022029999004021.

Pandey, P. K., and H. S. Ramaswamy. 2004. Effect of high-pressure treatment of milk on lipase and gamma-glutamyl transferase activity. J. Food Biochem. 28:449-462. https://doi.org/10.1111/j.1745 $-4514.2004 .02603 . x$.

Pereda, J., V. Ferragut, J. M. Quevedo, B. Guamis, and A. J. Trujillo. 2007. Effects of ultra-high pressure homogenization on microbial and physicochemical shelf life of milk. J. Dairy Sci. 90:1081-1093. https://doi.org/10.3168/jds.S0022-0302(07)71595-3.

Pizzano, R., C. Manzo, M. Adalgisa Nicolai, and F. Addeo. 2012. Occurrence of major whey proteins in the $\mathrm{pH} 4.6$ insoluble protein fraction from UHT-treated milk. J. Agric. Food Chem. 60:80448050. https://doi.org/10.1021/jf3024563.

Rasanayagam, V., V. M. Balasubramaniam, E. Ting, C. E. Sizer, C. Bush, and C. Anderson. 2003. Compression heating of selected fatty food materials during high-pressure processing. J. Food Sci. 68:254-259. https://doi.org/10.1111/j.1365-2621.2003.tb14148.x.

Roach, A., and F. Harte. 2008. Disruption and sedimentation of casein micelles and casein micelle isolates under high-pressure homogenization. Innov. Food Sci. Emerg. Technol. 9:1-8. https://doi.org/10 .1016/j.ifset.2007.03.027.

Rodarte, D., A. Zamora, A.-J. Trujillo, and B. Juan. 2018. Effect of ultra-high pressure homogenization on cream: Shelf life and physicochemical characteristics. Lebensm. Wiss. Technol. 92:108-115. https://doi.org/10.1016/j.lwt.2018.02.020.

Rowland, S. J. 1937. 157. The creaming power of heated milk. The relationship between the denaturation of albumin and globulin and the reduction in creaming power. J. Dairy Res. 8:195-202. https:/ /doi.org/10.1017/S0022029900002041.

Ruiz-Espinosa, H., G. G. Amador-Espejo, M. E. Barcenas-Pozos, J. O. Angulo-Guerrero, H. S. Garcia, and J. Welti-Chanes. 2013. Multiple-pass high-pressure homogenization of milk for the development of pasteurization-like processing conditions. Lett. Appl. Microbiol. 56:142-148. https://doi.org/10.1111/lam.12027.

Sandra, S., and D. G. Dalgleish. 2007. The effect of ultra high-pressure homogenization $(\mathrm{UHPH})$ on rennet coagulation properties of unheated and heated fresh skimmed milk. Int. Dairy J. 17:1043-1052. https://doi.org/10.1016/j.idairyj.2007.01.005.

Sauer, A., and C. I. Moraru. 2012. Heat stability of micellar casein concentrates as affected by temperature and $\mathrm{pH}$. J. Dairy Sci. 95:6339-6350. https://doi.org/10.3168/jds.2012-5706.

Scollard, P. G., T. P. Beresford, E. C. Needs, P. M. Murphy, and A. L. Kelly. 2000. Plasmin activity, $\beta$-lactoglobulin denaturation and proteolysis in high pressure treated milk. Int. Dairy J. 10:835-841. https://doi.org/10.1016/S0958-6946(01)00028-0.
Stratakos, A. C., E. S. Inguglia, M. Linton, J. Tollerton, L. Murphy, N. Corcionivoschi, A. Koidis, and B. K. Tiwari. 2019. Effect of high pressure processing on the safety, shelf life and quality of raw milk. Innov. Food Sci. Emerg. Technol. 52:325-333. https://doi.org/10 .1016/j.ifset.2019.01.009.

Tahiri, I., J. Makhlouf, P. Paquin, and I. Fliss. 2006. Inactivation of food spoilage bacteria and Escherichia coli $\mathrm{O} 157: \mathrm{H} 7$ in phosphate buffer and orange juice using dynamic high pressure. Food Res. Int. 39:98-105. https://doi.org/10.1016/j.foodres.2005.06.005.

Takagi, A., N. Yamashita, T. Yoshioka, Y. Takaishi, K. Sano, H. Yamaguchi, A. Maeda, K. Saito, Y. Takakura, and M. Hashida. 2007. Enhanced pharmacological activity of recombinant human interleukin-11 (rhIL11) by chemical modification with polyethylene glycol. J. Control. Release 119:271-278. https://doi.org/10.1016/j .jconrel.2007.03.009.

Thiebaud, M., E. Dumay, L. Picart, J. P. Guiraud, and J. C. Cheftel. 2003. High-pressure homogenisation of raw bovine milk. Effects on fat globule size distribution and microbial inactivation. Int. Dairy J. 13:427-439. https://doi.org/10.1016/S0958-6946(03)00051-7.

Tobin, J., S. P. Heffernan, D. M. Mulvihill, T. Huppertz, and A. L. Kelly. 2015. Applications of high-pressure homogenization and microfluidization for milk and dairy products. Pages 93-114 in Emerging Dairy Processing Technologies: Opportunities for the Dairy Industry. Datta, N. and P. Tomasula. ed. John Wiley \& Sons, Chichester, UK.

Tornberg, E. 1980. Functional characteristics of protein stabilized emulsions: Emulsifying behavior of proteins in a sonifier. J. Food Sci. 45:1662-1668. https://doi.org/10.1111/j.1365-2621.1980 .tb07585.x.

Tunick, M. H., D. X. Ren, D. L. Van Hekken, L. Bonnaillie, M. Paul, R. Kwoczak, and P. M. Tomasula. 2016. Effect of heat and homogenization on in vitro digestion of milk. J. Dairy Sci. 99:4124-4139. https://doi.org/10.3168/jds.2015-10474

Walstra, P., and R. Jenness. (1984). Milk fat globules. Pages 254-300 in Dairy Chemistry and Physics. John Wiley \& Sons, New York, NY.

Wiking, L., and J. A. Dickow. 2013. Effect of homogenization temperature and pressure on lipoprotein lipase activity and free fatty acids accumulation in milk. Food Sci. Nutr. 04:101-108. https:// doi.org/10.4236/fns.2013.48A013.

Ye, A., S. G. Anema, and H. Singh. 2004. High-pressure-induced interactions between milk fat globule membrane proteins and skim milk proteins in whole milk. J. Dairy Sci. 87:4013-4022. https:// doi.org/10.3168/jds.S0022-0302(04)73542-0.

Zamora, A., V. Ferragut, P. D. Jaramillo, B. Guamis, and A. J. Trujillo. 2007. Effects of ultra-high pressure homogenization on the cheese-making properties of milk. J. Dairy Sci. 90:13-23. https:// doi.org/10.3168/jds.S0022-0302(07)72604-8.

\section{ORCIDS}

Jerish Joyner Janahar (1) https://orcid.org/0000-0003-0921-3646 V. M. Balasubramaniam ( ) https://orcid.org/0000-0002-1540-4273 Rafael Jimenez-Flores (ํ) https://orcid.org/0000-0003-4905-5021 